Arq. Bras. Med. Vet. Zootec., v.56, n.6, p.695-700, 2004

\title{
Pharmacokinetics of sodium meclofenamate in pre-ruminant cattle
}

\author{
[Farmacocinética do meclofenamato sódico em bezerros pré-ruminantes] \\ E.J. Picco ${ }^{1}$, D.C. Diaz David ${ }^{1}$, T. Encinas ${ }^{2}$, M.R. Rubio ${ }^{1}$, J.C. Boggio ${ }^{1 *}$ \\ ${ }^{1}$ Cátedra de Farmacologia - Facultad de Ciencias Veterinarias \\ Universidad Nacional del Litoral \\ R.P.Kreder 2805 - (3080) Esperanza, Argentina \\ ${ }^{2}$ Department of Pharmacology - Veterinary School - Complutense University of Madrid, Spain
}

\begin{abstract}
The pharmacokinetic profile of sodium meclofenamate, a non-steroidal antiinflammatory drug, was determined in six pre-ruminant calves after intravenous and intramuscular administration at a dose of $2.2 \mathrm{mg} / \mathrm{kg}$ of body weight. Meclofenamate concentrations were measured using a high performance liquid chromatography assay. The pharmacokinetics of sodium meclofenamate after intravenous and intramuscular administration to calves were characterised by a rapid distribution phase $\left(\mathrm{t}_{1 / 2 \alpha}\right)$, $15.45 \pm 4.85 \mathrm{~min}$ and $23.14 \pm 7.24 \mathrm{~min}$ for the intravenous and intramuscular administration, respectively, followed by a longer elimination phase $\left(\mathrm{t}_{1 / 2 \beta}\right)$ after intramuscular treatment $(17.55 \pm 6.52 \mathrm{~h}$.). The apparent volume of distribution $\left(\mathrm{V}_{\mathrm{d}}\right)$ of the drug after intravenous administration was moderate $(0.72 \pm 0.12 \mathrm{l} / \mathrm{kg})$, and high $(3.51 \pm 1.05 \mathrm{l} / \mathrm{kg})$ after intramuscular administration. This can be explained by the flip-flop effect or by enterohepatic shunting. The bioavailability achieved after intramuscular administration was $61 \%$.
\end{abstract}

Keywords: calf, sodium meclofenamate, pharmacokinetic, pre-ruminant

\section{RESUMO}

O perfil do meclofenamato sódico, uma droga antiinflamatória não-esteroidal, foi determinado em seis bezerros pré-ruminantes após administração intravenosa e intramuscular na dose de 2,2mg/kg de peso vivo. As concentrações de meclofenamato foram medidas empregando-se cromatografía líquida de alta performance. A farmacocinética do meclofenamato sódico, após as administrações intravenosa e

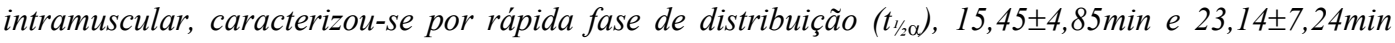
para a administração intravenosa e intramuscular, respectivamente, seguida por longa fase de eliminação ( $\left.t_{1 / 2 \beta}\right)$, após a aplicação intramuscular $(17,55 \pm 6,52 \mathrm{~h}$.). O volume aparente de distribuição $(\mathrm{Vd})$ da administração intravenosa da droga foi moderado $(0,72 \pm 0,12 \mathrm{l} / \mathrm{kg})$, e após um lapso da aplicação intramuscular, foi alta $(3,51 \pm 1,05 \mathrm{l} / \mathrm{kg}$ ). Isso pode ser explicado pelo efeito flip-flop ou por evitar a via enteroépatica. A biodisponibilidade obtida após administração intramuscular foi de $61 \%$.

Palavras-chave: bezerro, pré-ruminante, meclofenamato sodico, farmacocinética

Recebido para publicação em 17 de janeiro de 2003

Recebido para publicação, após modificações, em 4 de fevereiro de 2004

*Corresponding author

E-mail: jcboggio@campus1.uccor.edu.ar 


\section{INTRODUCTION}

Sodium meclofenamate is the sodium salt of meclofenamic acid [N - (2.6 dicholoro -m-tolyl) anthranilic acid], a non-steroidal antiinflammatory drug (NSAIDs) belonging to the fenamate group, which is structurally related to tolfenamic acid. This compound has been shown to possess anti-inflammatory, analgesic and antipyretic properties. It can be useful for treating a variety of conditions such as mastitis, musculoeskeletal disorders, pneumonies and fever (Boothe, 1995; Koup et al., 1990). This drug has also been used for prophylaxis and treatment of experimental anaphylaxis in cattle (Aitken et al., 1975), but this use was discontinued.

Similarly to other NSAIDs, it has been generally accepted that the mechanism of action of sodium meclofenamate is the inhibition of cyclooxygenase (COX), the enzyme that converts arachidonic acid into inflammatory mediators such as prostaglandins $\mathrm{E}_{2}$ and $\mathrm{I}_{2}$ and the pro-agregatory agent tromboxane $\mathrm{A}_{2}$ (Vane, 1971).

At present, it is known that COX exists in at least two isoforms, cyclooxygenase-1 (COX-1) and cyclooxygenase- 2 (COX-2). COX-1 is a constitutive enzyme involved in what have been described as 'housekeeping' functions, including blood clotting, regulation of vascular homeostasis, renoprotection, gastroprotection and coordination of the actions of circulating hormones. COX-2 is normally absent in tissues but may be induced by mitogens, lipopolysaccharide and other inflammatory mediators. Sodium meclofenamate blocks COX1 and COX-2 non-selectively at clinical dose rates (Vane and Botting, 1995). Other investigators have studied the plasma concentration - time relationship for sodium meclofenamate administered intravenously, orally, intraruminaly (Aitken and Sandford, 1975) and intramuscularly (Marriner and Bogan, 1979) to cattle. However, the pharmacokinetic parameters were not determined.

Pharmacokinetic properties of sodium meclofenamate vary greatly among species (Boothe, 1995); in sheep the elimination half life is prolonged, compared with that reported for cattle (Aitken et al., 1975; Encinas et al., 1995;
Encinas et al., 1996). Variation in the pharmacokinetics of NSAIDs is not only observed among species, but also within species, owing to the effects of age. It is well known that a difference in pharmacokinetic behaviour may exist between newborns and adult animals, which may be related to changes of total body water content, extracellular fluid volume, protein binding capacities, hepatic metabolic function and renal function and, in ruminants, also to the developmental stage of the forestomach system (Schwark, 1992; Nouws, 1992).

The objective of this study was to describe the pharmacokinetic parameters of sodium meclofenamate in pre-ruminant calves after intravenous (IV) and intramuscular (IM) administration.

\section{MATERIALS AND METHODS}

Six clinically healthy pre-ruminant Holstein male calves, 1 to 2 weeks old and weighing between 45 and $50 \mathrm{~kg}$ were used. They were housed in individual pens and were fed with a commercial milk replacer twice a day. All procedures on animals were approved by the Institutional Animal Care and Use Committee.

The calves were individually weighed and randomly assigned to two groups, $\mathrm{A}$ and $\mathrm{B}$. Group A received $2.2 \mathrm{mg} / \mathrm{kg}$ of sodium meclofenamate intravenously, while in groups B, the same dose was given intramuscularly. After a period of one week, a classical cross-over design was applied.

In the IV study, sodium meclofenamate was administered by bolous injection into the left jugular vein through a catheter, while for IM study the drug was administered into the left semitendinous muscle. In both phases animals received sodium meclofenamate as a $10 \%$ solution in water - propylenglycol 400 (75:25, $\mathrm{v} / \mathrm{v})$.

Blood samples $(5 \mathrm{ml})$ were collected in heparinized tubes from the right jugular vein immediately before administration and at 5, 15, $30,45,60,90 \mathrm{~min}$, and 2, 4, 6, 8, 10 and 24 hours after intravenous administration and at 5 , $15,30,45,60,90 \mathrm{~min}$ and 2, 3, 4, 6, 8, 10, 24, 36 and 48 hours post- intramuscular dosing. Plasma 
was separated by blood centrifugation at 3000 rpm for 15 minutes and stored at $-20^{\circ} \mathrm{C}$ until analysed, two weeks later.

Sodium meclofenamate plasma concentrations were measured by high performance liquid chromatography (HPLC). In a test tube, $0.5 \mathrm{ml}$ of plasma was mixed with $0.5 \mathrm{ml}$ of $\mathrm{HCl}(6 \mathrm{~N})$. The sample was mixed for $2 \mathrm{~min}$, and $5 \mathrm{ml}$ of methylene chloride was added. It was mixed (2min) and centrifuged at 3500rpm for $10 \mathrm{~min}$. The organic layer $(4 \mathrm{ml})$ was transferred to another test tube, evaporated to dryness $\left(40^{\circ} \mathrm{C}\right.$, nitrogen stream), redissolved in $200 \mu 1$ of mobile phase and a $20 \mu \mathrm{l}$ volume was injected into the chromatographic system.

The HPLC analyses were carried out on a model 500 B HPLC system with an UV detector at $226 \mathrm{~nm}$. The mobile phase consisted of acetonitrile:methanol:water $(\mathrm{pH} 2.5$, phosphate buffer) (20:40:40), and the flow rate was $1.5 \mathrm{ml} / \mathrm{min}$. The reverse phase column was a $5 \mu \mathrm{m}$ Spherisorb C-18 (25cm $\times 4 \mathrm{~mm}$, i.d.).

Peak areas in the sample chromatograms were quantitated using the external standard technique. Under these conditions, the retention time for the drug was $4.86 \mathrm{~min}$, average recovery percentage was $95.4 \%$, intra-assay variation was $8.3 \%$ and inter-assay variation was $8.6 \%$ and the limit of detection was $0.39 \mu \mathrm{g} / \mathrm{ml}$.

Pharmacokinetic analysis of plasma concentration versus time data for sodium meclofenamate was performed using a computer software package using routine equations (Gibaldi and Perrier, 1982).

A biexponential equation was used to describe the plasma disposition kinetics of sodium meclofenamate after intravenous administration, while a triexponential equation was used for intramuscular application. The rate constants, $K_{a b}, \alpha$ and $\beta$, were estimated using least-square regression analysis of the concentration-time data obtained during the log linear absorption, distribution and elimination phases, respectively. The absorption, distribution and elimination half- lives $\left(t^{1 / 2}\right)$ were calculated as in 2 divided by the rate constants.

The maximum concentrations $\left(C_{\max }\right)$ and time to $C_{\max }\left(T_{\max }\right)$ for sodium meclofenamate in plasma were extrapolated from the plotted concentration-time curve for each animal.

The area under the concentration - time curves ( $A U C)$ were calculated by the trapezoidal rule (Gibaldi and Perrier, 1982) and further extrapolated to infinity by dividing the last experimental concentration by the terminal slope $(\beta)$.

The total body clearance of sodium meclofenamate in plasma $(\mathrm{Cl})$ and volume of distribution ( $V d$ area) were calculated using the conventional equation described by (Gibaldi and Perrier, 1982).

Mean residence times $(M R T)$ were calculated as $M R T=A U M C / A U C$, where $A U C$ is the area under the concentration versus time curve from zero to infinity and $A U M C$ is the area under the curve of the product of time and plasma drug concentration versus time from 0 to infinity.

The value of bioavailability $(F)$ was obtained by the method of corresponding areas:

$\mathrm{F}(\%)=\frac{\mathrm{AUC}_{\mathrm{IM}}}{\mathrm{AUC}_{\mathrm{IV}}} \times 100$

Pharmacokinetic variables were expressed as mean and standard deviation (SD). The mean pharmacokinetic variables for the parent drug obtained for the different treatments were compared using the Wilcoxon signed-rank test. Means were considered significantly different at $(\mathrm{P}<0.05)$.

\section{RESULTS}

The mean plasma concentration - time profiles of meclofenamate following intravenous and intramuscular administration are shown in Figure 1. Mean values of pharmacokinetic parameters for each route of administration are presented in Table 1. 


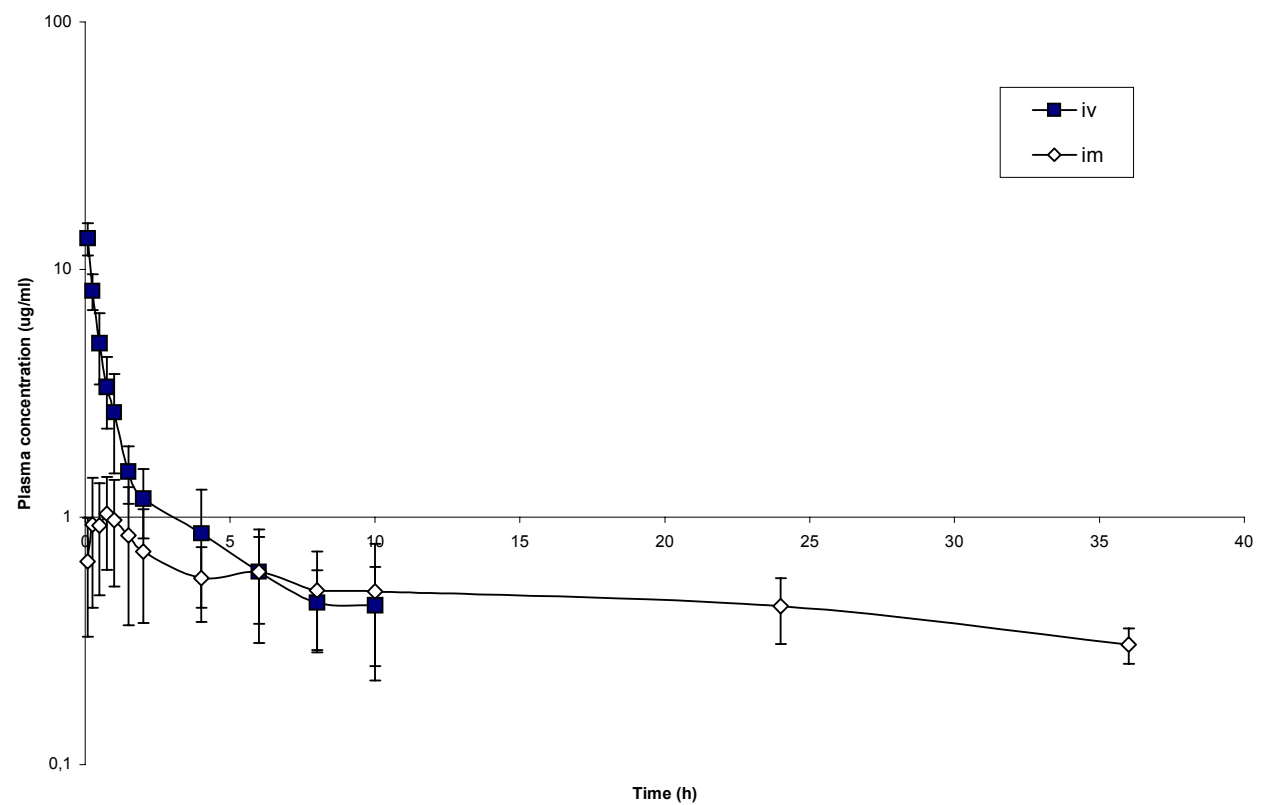

Figure 1. Mean plasma concentration - time profiles of sodium meclofenamate in pre-ruminant calves after intravenous and intramuscular doses of $2.2 \mathrm{mg} / \mathrm{kg}$.

Table 1. Pharmacokinetic parameters (mean \pm SD) of sodium meclofenamate $(2.2 \mathrm{mg} / \mathrm{kg})$ after intravenous and intramuscular administration

\begin{tabular}{|c|c|c|}
\hline Parameters & $\begin{array}{l}\text { Intravenous } \\
\quad(\mathrm{n}=6)\end{array}$ & $\begin{array}{c}\text { Intramuscular } \\
(\mathrm{n}=6)\end{array}$ \\
\hline$K_{a b}(1 / \mathrm{min})$ & - & $0.0572 \pm 0.0270$ \\
\hline$T_{1 / 2 a b}(\min )$ & - & $14.44 \pm 6.83$ \\
\hline$\alpha(1 / \min )$ & $0.048 \pm 0.013$ & $0.0327 \pm 0.0115$ \\
\hline$T_{1 / 2 \alpha}(\min )$ & $15.45 \pm 4.85$ & $23.14 \pm 7.24$ \\
\hline$\beta(1 / \mathrm{min})$ & $0.0035 \pm 0.0005$ & $0.000756 \pm 0.0003283$ \\
\hline$T_{1 / \beta \beta}(\mathrm{h})$ & $3.28 \pm 0.4$ & $17.55 \pm 6.52$ \\
\hline $\mathrm{Co}(\mu \mathrm{g} / \mathrm{ml})$ & $15.58 \pm 3.51$ & - \\
\hline $\mathrm{C}_{\max }(\mu \mathrm{g} / \mathrm{mL})$ & - & $1.13 \pm 0.40$ \\
\hline $\mathrm{T}_{\max }(\min )$ & - & $45.00 \pm 13.42$ \\
\hline AUMC $(\mu \mathrm{g} \cdot \mathrm{h} \cdot \mathrm{h} / \mathrm{ml})$ & $50.81 \pm 19.38$ & $421.77 \pm 219.51$ \\
\hline$A U C(0-\mathrm{t})(\mu \mathrm{g} \cdot \mathrm{h} / \mathrm{ml})$ & $14.69 \pm 2.71$ & $9.43 \pm 5.05$ \\
\hline$M R T(\mathrm{~h})$ & $3.39 \pm 0.78$ & $24.51 \pm 9.13$ \\
\hline$V d_{\text {(area) }}(1 / \mathrm{k}$ & $0.72 \pm 0.12$ & $3.49 \pm 1.05$ \\
\hline $\mathrm{Cl}(\mathrm{ml} / \mathrm{min} / \mathrm{kg})$ & $2.56 \pm 0.43$ & $2.47 \pm 0.99$ \\
\hline
\end{tabular}

$\mathrm{K}_{\mathrm{ab}}$ : hybrid constant for absorption; $\mathrm{T}_{1 / 2 \mathrm{ab}}$ : absorption phase half-life; $\alpha$ : hybrid constant for distribution; $\mathrm{T}_{1 / 2 \alpha}$ : distribution phase half-life; $\beta$ : hybrid constant for elimination; $T_{1 / 2 \beta}$ : elimination phase half-life; $\mathrm{C}_{\mathrm{o}}$ : estimated initial drug concentration; $\mathrm{C}_{\max }$ : maximal plasma concentration; $\mathrm{T}_{\max }$ : time of $\mathrm{C}_{\max }$; AUMC: area under moment curve; AUC: area under curve; MRT: mean residence time; $\mathrm{Vd}_{(\text {area) }}$ : apparent volume of distribution; $\mathrm{Cl}$ : total body clearance

The disposition of sodium meclofenamte after intravenous and intramuscular administration was characterized by a rapid distribution phase followed by a longer elimination phase.
After intramuscular administration the maximum plasma concentrations $(1.13 \pm 0.4 \mu \mathrm{g} / \mathrm{ml})$ were obtained within $45 \pm 13,42 \mathrm{~min}$ and the drug was not detected after $36 \mathrm{~h}$ post administration. The bioavailability of the drug was $61 \%$.

\section{DISCUSSION}

The pharmacokinetics of sodium meclofenamate after intravenous and intramuscular administration to calves, as well as those reported in several animals species, have been best described using a two - compartment open models (Aitken and Sandford, 1975; Encinas et al., 1995; Johansson et al., 1991).

The disposition of the drug after intravenous administration was characterised by a rapid fall in plasma levels $\left(t_{1 / 2 \alpha}=15.45 \pm 4.85 \mathrm{~min}\right)$, which is in agreement with observations reported previously in adult cattle $\left(\mathrm{t}_{1 / 2 \alpha}=20 \mathrm{~min}\right)$ (Aitken and Sandford, 1975). No significant differences were seen in the elimination half-life of sodium meclofenamate between our results and the values reported previously by the same authors in cattle $\left(\mathrm{t}_{1 / 2 \beta}=3.1 \mathrm{~h}\right.$ and $\mathrm{t}_{1 / 2 \beta}=4.0 \mathrm{~h}$, respectively). 
However, the values were lower than those reported in adult sheep $\left(t_{1 / 2}=9.03 \mathrm{~h}\right)$ (Encinas et al., 1995; Encinas et al., 1996).

After intramuscular administration, the elimination half life was longer $\left(t_{1} / 2=\right.$ $17.57 \pm 6.52 \mathrm{~h}$ ) than after intravenous application. The same situation was observed for tolfenamic acid, where the $t_{1 / 2 \beta}$ in the cattle change from $2.5 \mathrm{~h}$ after IV to $8,01 \mathrm{~h}$ for the IM route (Lees et al., 1998).

Absorption of sodium meclofenamate seemed to be rapid. Mean absorption half-life was $14.44 \pm 6.83 \mathrm{~min}$ and mean $T_{\max }$ was $45.00 \pm 13.42 \mathrm{~min}$. However, $T_{\max }$ is a hybrid parameter that depends on constants of absorption, distribution and elimination. Consequently, a very short $T_{\max }$ can be observed with a very long process of absorption.

The mean plasma concentrations after intramuscular dosing declined from $1.13 \pm 0.4 \mu \mathrm{g} / \mathrm{ml}$ at $45 \mathrm{~min}$ to $0.29 \mu \mathrm{g} / \mathrm{ml}$ at 24 hours. These values were considerably lower than the levels of more than $2 \mu \mathrm{g} / \mathrm{ml}$ required for efficacy in suppressing allergic respiratory reactions in cattle (Aitken et al., 1975).

The apparent volume of distribution $\left(V d_{\text {area }}\right)$ of NSAIDs is generally very small, primarily because of the extent to which they are bound to plasma proteins. In this study, the $V d_{\text {area }}$ of the drug after intravenous administration was medium $\left(V d_{\text {area }}=0.72 \pm 0,12 \mathrm{l} / \mathrm{kg}\right)$, but after intramuscular application it was high $(3.51 \pm 1.2 l / \mathrm{kg})$. A large $V d$ may be expected in pre-ruminant calves because of the large volume of extracellular fluid and the low plasma protein concentration present in neonate animals. However, the value of $V d$ was surprisingly higher after the IM than the EV route.

In previous studies using tolfenamic acid, a NSAIDs of the fenamate group, the $\mathrm{V}_{\mathrm{d}}$ was also higher after intramuscular $\left(V d_{\text {area }}=1.79 l / \mathrm{kg}\right)$ than intravenous $\left(V d_{\text {area }}=0.98 \mathrm{l} / \mathrm{kg}\right.$ ) injection (Landoni et al., 1996; Lees et al., 1998).

The longer elimination half-life and greater $V_{d}$ reported after intramuscular administration can be explained by the flip-flop effect (Gibaldi and Perrier, 1982), which arises when the rate of elimination of the drug is greater than the rate of absorption. The flip-flop phenomenon was also described in equine after oral and intramuscular administration of sodium meclofenamate (Snow et al., 1981).

Another likely explanation for the large distribution volume is the enterohepatic shunting. Biliary excretion and reabsorption of fenamate metabolites has been demonstrated in dogs and monkeys (Glazco, 1966).

The bioavailability was of $61 \%$. It is higher than in horses $(F=46 \%)$ for the same route of administration (Snow et al., 1981) and in sheep $(\mathrm{F}=45.8$ to $55.4 \%)$ after oral administration (Encinas et al., 1996) of sodium meclofenamate.

It is possible that extensive tissue binding of the drug at the site of administration may be responsible for the apparent reduction in bioavailability and the relatively slow release of the drug, although it was not evaluated (Snow et al., 1981).

In conclusion, the results of this study have demonstrated that high blood levels of sodium meclofenamate are achieved after intravenous administration, although this levels are not maintained along time. The low $C_{\max }$ achieved after intramuscular administration suggests that a higher dose must be used to achieve therapeutic concentrations.

\section{REFERENCES}

AITKEN, M.; SANFORD, J. Plasma levels following administration of sodium meclofenamate by various routes. Res. Vet. Sci., v.19, p.241-244, 1975.

AITKEN, M.; SANFORD, J.; EVANS, D. Prophylaxis and treatment of experimental anaphylaxis in cattle by sodium meclofenamate. Res. Vet. Sci., v.18, p.41-48, 1975.

BOOTHE, D.M. The analgesic - antipyretic antiinflammatory drug. In: ADAMS, R. (Ed.). Veterinary pharmacology and therapeutics. 7.ed. Ames: Iowa State University, 1995. p.432-443.

ENCINAS, T.; VINAGRE, E.; BOGGIO, J.C. et al. Comparison of the kinetics of sodium meclofenamate after oral administration to sheep. 
J. Vet. Med. A., v.42, p.177-183, 1995.

ENCINAS, T.; VINAGRE, E.; BOGGIO, J.C. et al. Influence of closure of the reticular groove on the biovailability and disposition kinetic of meclofenamate in sheep. J. Vet. Pharmacol. Therap., v.19, p.15-21, 1996:

GIBALDI, M.; PERRIER, D. Pharmacokinetics, drugs and pharmaceutical sciences. 2.ed. New York, 1982. P.145-198.

GLAZKO, A. In: Fenamates and Medicine. Supplement to Annals of Physical Medicine, A Symposium. London: Ed. P. Hume Kendall, 1966. p.23.

JOHANSSON, I.M.; KALLINGS, P.; HAMMARLUIND-UDENAES, D.M. Studies of meclofenamic acid and two metabolites in horses - pharmacokinetics and effects on exercise tolerance. J. Vet. Pharmacol. Therap., v.14, p.235-242, 1991.

KOUP, J.R.; TUCKER, E.; THOMAS, D.J. et al. A single and multiple dose pharmacokinetic and metabolism study of meclofenamate sodium. Biopharm. Drug Dispos., v.1, p.1-15, 1990.

LANDONI, M.F.; CUNNINGHAM F.M.; LEES, P. Pharmacokinetics and pharmacodynamics of tolfenamic acid in calves. Res. Vet. Sci., v.61, p.26-32, 1996.
LEES, P.; MCKELLAR, Q.; FOOT, R. et al. Pharmacodynamics and pharmacokinetics of tolfenamic acid in ruminating calves: Evaluation in models of acute inflammation. Vet. J., v.155, p.275-288, 1998.

MARRINER, S.; BOGAN, J.A. The influence of the rumen on the absorption of drugs: studies using meclofenamic acid administered by various routes to sheep and cattle. J. Vet. Pharmacol. Therap., v.2, p.109-115, 1979.

NOUWS, J. Pharmacokinetics in immature animals: a review. Anim. Sci., v.70, p.3627-3634, 1992.

SCHWARK, W. Factors that affect drug disposition in food-producing animals during maturation. Anim. Sci., v.70, p.3635-3645, 1992.

SNOW, D.; BAXTER, P.; WHITING, B.: The pharmacokinetics of meclofenamic acid in the horse. J. Vet. Pharmacol. Therap., v.4, p.147156, 1981.

VANE, J.R. Inhibition of prostaglandin synthesis as a mechanism of action for aspirin - like drugs. Nature, v.231, p.232-235, 1971.

VANE, J.R., BOTTING, R.M. New insights into the mode of action of anti-inflammatory drugs. Inflamm. Res., v.44, p.1-10, 1995. 